\title{
地震時における多層骨組の最大変形とエネルギー応答 THE MAXIMUM DISPLACEMENT AND ENERGY RESPONSE OF MULTI-STORY FRAMES UNDER EARTHQUAKES
}

\author{
高橋 誠*, 秋 山 宏** \\ Makoto TAKAHASHI and Hiroshi AKIYAMA
}

\begin{abstract}
The structural behavior of structures under earthquakes can be clearly described on the basis of the balance of the input energy by earthquakes and the energy absorption capacity of structures. In practical seismic design, not only cumulative inelastic deformations which can be directly related to the energy absorption capacity but also the maximum plastic deformations and residual inelastic deformation must be precisely estimated. In this paper, the deformation responses of the multi-story moment frames are obtained by numerical analyses and the relationship between cumulative deformations and the maximum deformations are made clear. The structural types are identified to be composite structures composed of elastic(flexible) elements and elastic-plastic(stiff) elements. The most important parameter which governs the deformation response is found to be the shear stress ratio between the flexible and stiff elements.
\end{abstract}

Keywords : input energy by earthquakes, energy absorption capacity, cumulative inelastic deformation, maximum plastic deformation, numerical analyses, composite structures composed of flexible and stiff elements

地震エネルギー大力, エネルギ一吸収能力, 累積塑性変形, 最大塑性変形, 数值解析, 柔剛混合構 造

\section{1. 序}

構造物に対する地震の荷重効果を表現する量として, 地震動が構 造物にもたらす入力エネルギーは最も重要である。その理由は後述 するように，構造物の吸収エネルギーは入力エネルギーと等しく， 構造物の吸収エネルギーが構造物の地震に対する応答の一つの総体 的な表現であるからである。これに対して, 地動の最大加速度, 最 大速度等は構造物の地震応答を直接表現し得ない。また, 種々の弾 性応答スペクトルも, 構造物の弾性挙動と対応するが, 弾塑性挙動 と直接对応しない。

入力エネルギーないし，入力エネルギーと構造物の 1 次固有周期 との関係を示すエネルギースペクトルを用いれば，構造物が弾性に 留まるか否かに関わらず，構造物が受ける荷重効果を直接的に表現 することができるり。地震により構造物に投入されたエネルギーの 一部は逸散減衰として地盤に放散される。この逸散減衰は近似的に 粘性減衰として扱うことができ，構造物の非線形挙動による履歴吸 収エネルギーに逸散減衰の効果を含めて考えることができる。

このよjに地震入力エネルギーは, 結果的には構造物にすべて吸 収されてしまうので, 構造物の累積塑性歪エネルギーが地震応答の 総体を表すものと云える。

構造設計において，累積塑性歪エネルギーと並んで重要な損傷の 尺度として, 最大変形が挙げられる。最大変形の厳密な推定は非線
形応答解析によって求めざるを得ないが，累積塑性歪エネルギーと ある種の对応関係にある。この関係を把握すれば，エネルギーの釣 合式に基づいて，設計に関わる構造物の重要な応答量が共に推定で きることになる。既に，これ迄に累積塑性歪エネルギーないし，累 積塑性変形量と最大変形との概略の関係は求められているが1), 本 諭文は地震動, 復元力特性の違いに着目した多層骨組の地震応答解 析を通して，より一般的に両者の対応関係を求めることを目的とし ている。

\section{2．累積塑性歪エネルギーと最大变形の関係}

一層骨組を考之れば，地震時の力の釣合式は次式で表現できる。 $M \ddot{x}+C \dot{x}+Q(x)=-M \ddot{z}_{0}$

ここで，M：骨組の総質量

$\ddot{z}_{0} \quad$ : 地動加速度

$x \quad$ : 骨組の地表面に対寸る相対変位

$C \quad$ : 減衰係数

$Q(x)$ : 骨組の復元力

上式の両辺に微少変形増分 $d x(な い し \dot{x} d t)$ を乗じて地動の継続 時間にわたって積分すれば次式のエネルギー釣合式が得られる1)。

$W_{e}+W_{h}+W_{p}=E$

ここで, $W_{e}:$ 弾性振動工ネルギー
* 東京大学:工学部建築学科 助手 $\cdot$ 博士 $($ 工学)

** 東京大学工学部建築学科 教授. 工博
Research Assoc., Dept. of Architecture, Faculty of Engineering, Univ. of Tokyo, Dr. Eng.

Prof., Dept. of Architecture, Faculty of Engineering, Univ. of Tokyo, Dr. Eng. 


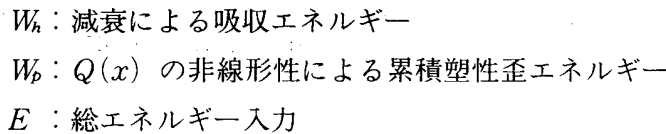

地動終了時には, 一般に弾性振動エネルギ一は殆ど消失している。 また， $W_{h}$ も一種の履歴吸收エネルギーと考えることができ $W_{p} に$ 含めて考えることにすれば，次式の表現が可能である。

$$
W_{p}=E
$$

$W_{p}$ は正の荷重領域でなされるエネルギ一吸収 $W_{p}^{+}$と負の荷重領 域でなされるエネルギー吸収 $W_{p}^{-}$の和であり，次式で表される。

$$
W_{p}=W_{p}^{+}+W_{p}^{-}
$$

骨組の一方向水平力下の荷重変形関係が図 1 に示されるものであ るとする。 $Q_{Y}$ は降伏耐力であり， $\delta_{Y}$ は $Q_{Y}$ に対応する弾性層間変位 である。一方向荷重下の塑性歪エネルギーを次式で定義する。

$$
W_{p m}=\int_{\delta r}^{\delta_{m}} Q d x
$$

ここで, $\delta_{m}$ : 最大層間変形。

$\delta_{m}$ を次式で表現すれば， $W_{p m}$ は $\mu$ の関数となる。

$\delta_{m}=(1+\mu) \delta_{Y}$

ここで, $\mu:$ 塑性変形倍率

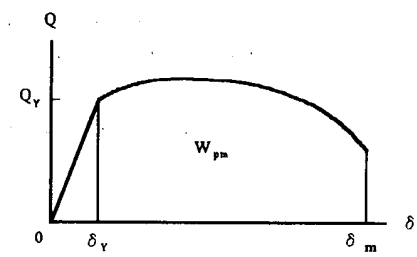

図 1：一方向水平力下の荷重変形関係

地震動下では骨組は正，負の荷重領域で最大変形 $\delta^{+}, \delta^{-}$を生ず る。 $\delta^{+}, \delta^{-}$に対応する $\mu$ を $\mu^{+}, \mu^{-}$とする。 $\mu^{+}, \mu^{-}$の平均值 $\bar{\mu}$ に 対応する $W_{p m}$ を用いて, (4)式は形式的に次式のように表現できる。

$$
\begin{aligned}
& W_{p}=2 W_{p m}(\bar{\mu}) a_{p} \\
& \text { ここで, } \bar{\mu}=\frac{\mu^{+}+\mu^{-}}{2}
\end{aligned}
$$

$a_{p}$ は係数で，(7)式より次式で定義される。

$$
a_{p}=\frac{W_{p}}{2 W_{p m}(\vec{\mu})}
$$

正, 負の荷重領域の䇣積塑性変形倍率 $\eta^{+}, \eta^{-}$, 累積塑性変形倍率 $\eta$ を次式で定義する。

$$
\left.\begin{array}{l}
\eta^{+}=\frac{W_{p}^{+}}{Q_{Y} \delta_{Y}}, \quad \eta^{-}=\frac{W_{p}^{-}}{Q_{Y} \delta_{Y}} \\
\eta=\frac{W_{p}}{Q_{Y} \delta_{Y}}=\eta^{+}+\eta^{-}
\end{array}\right\}
$$

$\eta^{+}, \eta^{-}$の内の大きい方の值を最大累積塑性変形倍率 $\eta_{m}$ とする。 $W_{p m}$ の無次元量 $A_{p m}$ を次式で定義する。

$$
\begin{aligned}
& A_{p m}=\frac{W_{p m}(\bar{\mu})}{Q_{Y} \delta_{Y}} \\
& \text { これ等の諸量を用いて, (7)式は次のように表される。 } \\
& \bar{\eta}=A_{p m}(\bar{\mu}) a_{p}
\end{aligned}
$$

ここで, $\bar{\eta}=\frac{\eta^{+}+\eta^{-}}{2}$ : 平均累積塑性変形倍率

一方向荷重下における荷重変形関係が完全弾塑性型である場合に は次式が成り立つ。

$$
A_{p m}=\dot{\bar{\mu}}
$$

従って，(11)式は次式に帰着する。

$$
\frac{\bar{\eta}}{\bar{\mu}}=a_{p}
$$

$\mu^{+}, \mu^{-}$の内の大きい方の值を最大塑性変形倍率 $\mu_{m}$ とする。 $\eta=$ $2 \bar{\eta}$ であり，次式が成立する。

$$
\frac{\eta}{\mu_{m}}=a_{p} \frac{2 \bar{\mu}}{\mu_{m}}
$$

$\bar{\mu} / \mu_{m}$ は最大変形の一方向への片寄りと考之れば，次式の範囲に ある。

$$
0.5 \leq \frac{\bar{\mu}}{\mu_{m}} \leq 1.0
$$

従って，(14)式から次式が得られる。

$$
a_{p} \leq \frac{\eta}{\mu_{m}} \leq 2.0 a_{p}
$$

$a_{p}, \bar{\mu} / \mu_{m}$ が定量化されれば, 最大変形, 累積塑性変形が入力エネ ルギーと対応づけられることになる。多首骨組の場合において，各 層の応答諸量に着目する場合には，(4)～(16)式は，層の位置を示す添 字 $i$ を添付することによってそのまま適用できる。その場合， $\mu$ は層 間変形に基づいて求められる。また，各層の累積塑性歪エネルギー を $W_{p i}$ とすれば，骨組全体の $W_{p}$ は次式で表せる。

$$
W_{p}=\sum W_{p_{i}}
$$

本論文では, 固有周期が 2.0 秒より短く，1 層建物をも含めた中低 層建物を想定し，それらを代表するものとして，層数 $N$ が10である 多層骨組を解析モデルとして採る。また，これ等に対する応答諸量 を，層の位置に関わらず定量化しょうとするものであることから㐫 答值に $i$ を付すことなく一層建物の場合と同様に表記する。

地震動としては，海洋型地震動を代表に十勝沖地震の八戸記録 $\mathrm{EW}$ 成分, 内陸型地震として Imperial Valley 地震 El Centro 記録 NS 成分，兵庫県南部地震 JMA 神戸 NS 成分を用いる。

\section{3 . 入力地震動の特性}

3-1 エネルギースペクトル

図 2 に解析に用いる地震動による臨界減衰比 $10 \% ， 1$ 質点弾性系 のエネルギースペクトルを示す。縦軸は総エネルギー入力 $E$ の次式 による速度換算值である。横軸は系の固有周期 $T$ (秒) である。

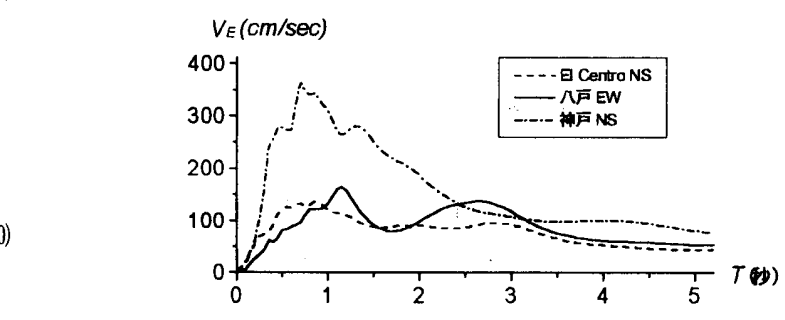

図 2 エネルギースペクトル 


$$
V_{E}=\sqrt{\frac{2 E}{M}}
$$

\section{ここで, $M:$ 質点の質量}

固有周期が 2 秒より短い領域において神戸 NS 波の入力が著しく 大きいことが特徴である。

\section{3-2 時刻歴エネルギー入力}

図 3 に各地震波による時刻歴エネルギー入力曲線を示す。地震動 継続時刻 $t$ における総エネルギー入力 $E(t)$ を地震終了時の総エネ ルギー入力に対する比率で表したものである。太実線は $h=0.1$, $T=1.0$ の 1 質点弾性系の時刻歴入力曲線であり, 曲線上の○印は最 大層間変位発生点である。細実線は $N=5$ で $T=1.00$ 無減衰完全 弾塑性系に对する時刻歴入力曲線であり, ○印は各層の最大層間変 位発生点である。降伏せん断力係数分布 $\bar{\alpha}_{i}$ は次の值である。

$$
\bar{\alpha}_{i}=\{1.0,1.10,1.25,1.53,2.01\}
$$

両曲線は強い对応関係にあり，10\%減衰 1 質点弾性系の時刻歴工 ネルギー入力が，同じ固有周期を持つ多質点弾塑性系の時刻歴工ネ ルギー入力を代表すると云える。このことは他の地震動及び振動系 に对しても同様に云えることである。最大変位は 1 質点系の場合,

○印の様に，急激に入力エネルギーが增大する時間に発生する。多 質点系の場合は○印の様に各層の最大変位の発生が一時期に集中す るとは限らない。

時刻歴エネルギ一入力曲線は, 地震動及び振動系の固有周期に よって変化するものの，一般的傾向として云えることは，入力が急 激に増大する極く短い時間に大部分のエネルギーが入力されること である2。瞬間的なエネルギ一入力は最大変形応答と密接な関係を 持っていると考之られ，1 質点系を対象に時刻歴エネルギー入力と

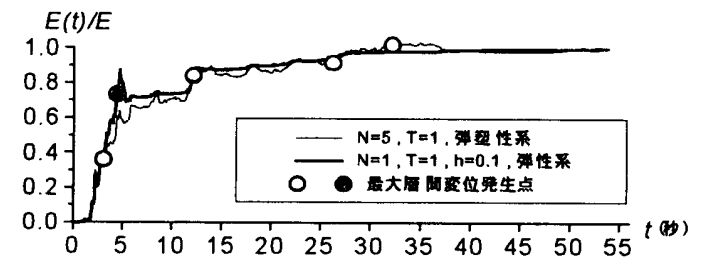

(a) El Centro NS
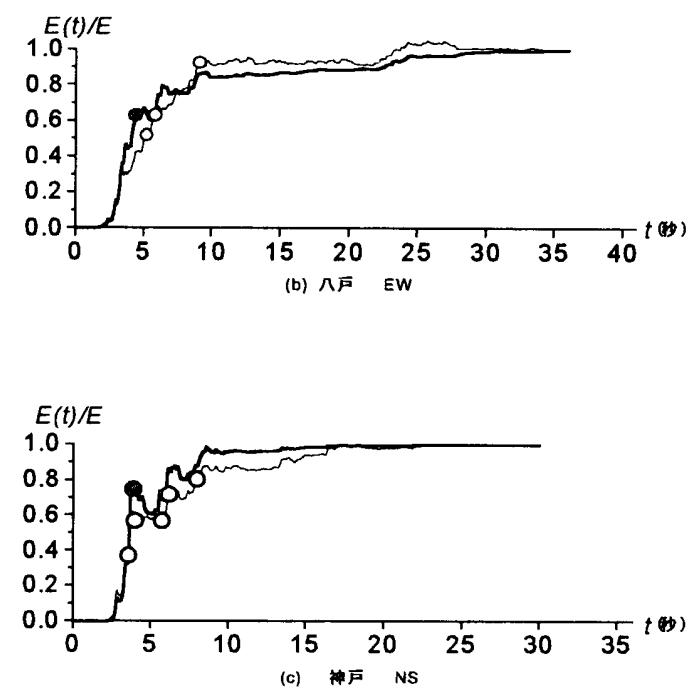

図 3 時刻歴エネルギー入力
最大変形応答とを対応づける試みが様々な方法でなされている が3,44,5),6(1,7)一般化するのは容易ではない。その理由は, 図 $3(\mathrm{a})$ の場合 のように多層骨組の場合における各層の最大変位はその層における 時刻歴入力特性に大きく依存するものであることと，一つの地震に 对して時刻歴エネルギー入力曲線は固有周期ごとに異なり複雑な様 相を呈することにある。図 4 には八戸記録に対する $h=0.1 の$ 場合の 1 質点弾性系のエネルギー入力の時刻歴を示すが，この図に示され るように，一般に時刻歴入力曲線は周期によっても異なり，また， 周期に对寸る変化に規則性がない。

地震終了時の総エネルギー入力は時刻歴入力の最終的な姿である が，そこには地震継続中に発生する最大変形の痕跡が含まれている はずであることから，地震終了時の総エネルギー入力との関係にお いて最大変形応答を評価する。

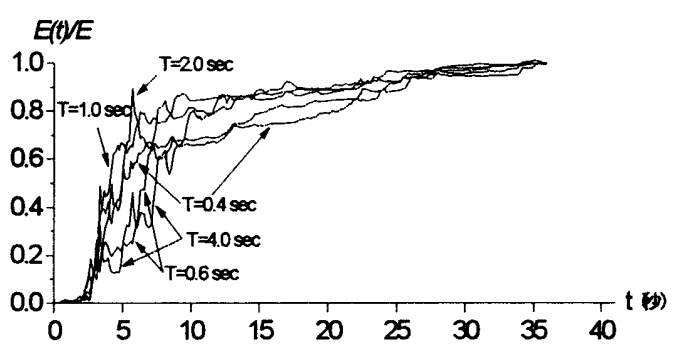

図 4 時刻歴エネルギー入力曲線の固有周期による変化

\section{4. 解析モデル}

せん断型多層骨組を解析対象とする。せん弾型多層骨組の一般形

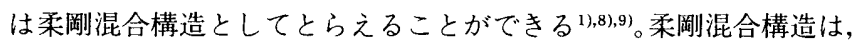
図 5 に示される様に弾性要素と弾塑性要素の混合構造である。弾性 要素の岡性は弾塑性要素の弾性風性と比べて小さく柔要素と見なさ れ，弾塑性要素は剛要素と見なされ，両者の混合構造が柔剛混合構 造と名付けられる。

柔要素を意罒的に設けない場合には弾塑性要素のみから成る単独 構造である。柔要素を導入することにより，図 5 (c)に示すように履 歴特性に原点へ復帰する指向性が生じ, 残留変形が減少し, 同一工 ネルギー入力に対して最大変形の抑制効果が生ずることが明らかに されている ${ }^{8), 9)}$

柔夙混合構造を特徵づけるものは，次式に示される采剛要素間の 剛性比 $r_{k}$, 及びせん断力比 $r_{q}$ である (図 5 参照)。

$$
r_{k}=\frac{k_{f}}{k_{s}}
$$
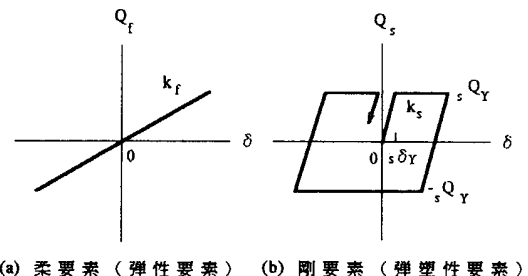

(b)㣚要索(弹塑性要素)

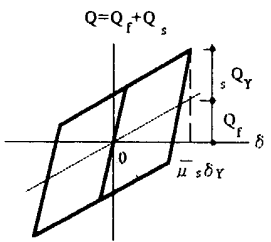

(c) 合成奻果

図 5 柔㴊混合構造 


$$
r_{q}=\frac{Q_{f}}{s Q_{Y}}
$$

ここで, $\quad k_{f}:$ 柔要素のバネ定数

$$
\begin{aligned}
& k_{s}: \text { 剛要素のバネ定数 } \\
& Q_{f}: \text { 柔要素の最大負担せん断力 }
\end{aligned}
$$$$
{ }_{s} Q_{Y}: \text { 剛要素の降伏せん断力 }
$$

平均最大変形応答 $\bar{\mu}_{s} \delta_{Y}\left({ }_{s} \delta_{Y}\right.$ : 剛要素の降伏変形 $)$ の下における $r_{q}$ は, ${ }_{s} Q_{Y}=k_{s} s_{S} \delta_{Y}, Q_{f}=k_{f}(1+\bar{\mu})_{s} \delta_{Y}$ であるから次式のように表現 できる。

$$
r_{q}=(1+\bar{\mu}) r_{k}
$$

$r_{k}$ は柔要素のみのバネによる固有周期 $T_{f}$ と剛要素のみのバネ による固有周期 $T_{s}$ で与える。表 1 に解析に用いた $T_{f}, T_{s}$ を示す。 $T$ は合成した固有周期である。

$k_{f}$ と ${ }_{s} Q_{Y}$ が一定の場合, $k_{s}$ が大きい程, 風要素の塑性化による工 ネルギ一吸収効率が高まり，一定の入力エネルギ一に对して最大変 形の抑制効果は強まる筈である。しかし， $k_{s}$ が大きい程 $r_{k}$ は小さく なる。この意味で $r_{k}$ は柔剛混合構造における最大変形抑制効果を 直接支配する量ではない。一方，ra澓歴特性における求心性を直 接表すもので, 変形抑制効果の主要因子となり゙得る。本論文では, $r_{q}$ を主要パラメータとして変形応答を整理する。

剛要素の復元力特性としては, 鋼構造剛接骨組を代表するものと して完全弾塑性型復元力特性と,それにいわゆる Bauschinger 効果 を付加したモデル10)を採りあげ，鉄筋コンクリート剛接骨組を代表 するものとして㴊性劣化型の復元力特性 (Clough モデル)を採りあ げる。

鋼構造骨組において，正，負の漸増変位繰返し荷重を受ける層の 水平せん断力と層間変位との関係は, 図 6 (a)に示すように骨格曲線 部, Bauschinger 部, 弾性除荷部に分けられる。繰返し曲線に㧍け る一つの荷重変形関係に着目すれば, B Bauschinger 部の途中で除荷

表 1 固有周期

\begin{tabular}{c|c|c|c}
\hline$T_{f}(\mathrm{sec})$ & $T_{s}(\mathrm{sec})$ & $\eta_{k}$ & $T(\mathrm{sec})$ \\
\hline & 0.25 & 0.01 & 0.249 \\
2.5 & 0.5 & 0.04 & 0.490 \\
& 0.75 & 0.09 & 0.718 \\
& 1.0 & 0.16 & 0.928 \\
\hline & 0.5 & 0.01 & 0.498 \\
5.0 & 1.0 & 0.04 & 0.981 \\
& 1.5 & 0.09 & 1.437 \\
& 2.0 & 0.16 & 1.857 \\
\hline 100.0 & & 0.0 & 0.500 \\
2.5 & & 0.04 & 0.490 \\
2.0 & 0.5 & 0.06 & 0.485 \\
1.5 & & 0.11 & 0.474 \\
1.0 & & 0.25 & 0.473 \\
\hline 100.0 & & 0.0 & 1.000 \\
5.0 & & 0.04 & 0.981 \\
4.0 & 1.0 & 0.06 & 0.970 \\
3.0 & & 0.11 & 0.949 \\
2.0 & & 0.25 & 0.894 \\
\hline 100.0 & & 0.0 & 2.000 \\
10.0 & & 0.04 & 1.961 \\
8.0 & 2.0 & 0.06 & 1.940 \\
6.0 & & 0.11 & 1.897 \\
4.0 & & 0.25 & 1.789 \\
\hline & & &
\end{tabular}

が起こらない場合の Bauschinger 部の形状は図 6(b)の様に描ける。 細実線は Bauschinger 部終端から除荷するとした場合の除荷曲線 である。(b)図中の $\delta_{B}$ は Bauschinger 振幅であり，この振幅の大きさ は，それまでに経過した繰返し履歴における骨格部の累積塑性変形 の大きさに比例して增大寸る傾问があることが分かっている10。比 例定数 $r_{B}$ を用いて Bauschinger 振幅 $\delta_{B}$ は次式によって与えられ る。

$\delta_{B}=r_{B} \sum \delta_{s}$

ここで, $\delta_{s}$ : 一つの Bauschinger 部が生ずるまでに正, 負の各荷 重領域で経験した骨格部の累積塑性変形。

$r_{B}$ の現実的な範围は $0.1 \leq r_{B} \leq 0.5$ と見積もられており ${ }^{10)}$, 本論文 では $r_{B}=0.5$ を用いている。Bauschinger 部は(b)四中に太破線で示 寸ように，弾性岡性と同一の公配を持つ線分と $0.5 s Q_{Y}$ 点から Bauschinger 部終端に向かう線分の 2 直線で近似する。骨格曲線部は完 全弹塑性型とする。

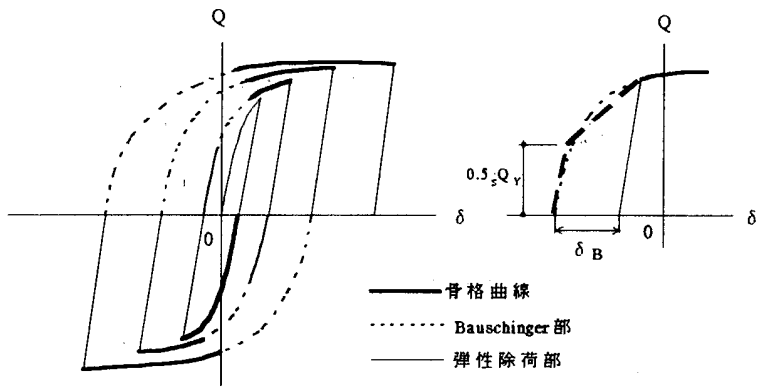

(a) 履歷曲線

(b) Bauschonger 部

図6 履糜曲線の分解

鉄筋コンクリート剛接骨組にお计る復元力特性を単純化した Clough モデルが図7に示されている。Clough モデルにおいては除 荷時バネ定数は弾性時のバネ定数に対して次式によって低減させ る。

$k_{u n}=k_{e}\left|r_{d Y}\right|^{-0.5}$ (23)

ここで， $r_{d Y}$ : 最大層間変形の降伏首間変形に対する比率。

本論文で対象とする柔剛混合構造では風要素のみが降伏する。入 力エネルギーに対して解析モデルの強度レベルを統一するために, ベースシア係数 $\alpha_{1}$ は次式で定められる值とする。

$$
\alpha_{1}=0.1 \times \frac{2 \pi V_{E}(T)}{g T}
$$

ここで, $V_{E}(T)$ :(18)式ないし図 2 より与えられる大力エネルギー

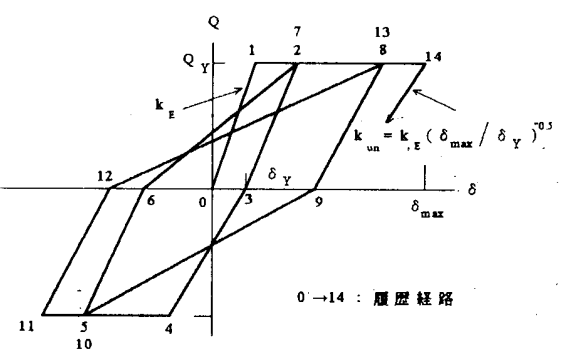

図 7 Clough モデル 
$g:$ 重力加速度。

(24)式は第 1 層の降伏せん断力係数が弾性限せん断力係数の $10 \%$ の值 であることを意味する。降伏せん断力係数分布 $\bar{\alpha}_{i}$ は次の值と寸る。 $V_{E}(T)$ を得るための $T$ は表 1 より与える。

$\bar{\alpha}_{i}=\alpha_{i} / \alpha_{1}=\{1.0,1.05,1.1,1.15,1.25$,

$1.38,1.52,1.7,2.01,2.66\}$

質量分布は一定值，バネ定数分布は強度分布に比例するものとす る。

\section{5. 応答解析結果}

\section{5-1 完全弾塑性型復元力特性を持つ場合}

四 8 には完全弾塑性型 $\left(r_{B}=0\right)$ の復元力特性を持つ場合の応答 を示す。いずれも横軸に(21)式に示す $r_{q}$ を採っている。

(a) 最大層間変形応答の片寄り

図 8(a)には $T_{f}=2.5 \mathrm{sec}$ の場合の $\mu_{m} / \bar{\mu}-r_{q}$ 関係を示す。 $r_{q}$ が増 大寸るにつれて最大塑性変形の片寄りは減少する傾向があり, $\mu_{m} / \bar{\mu}$ の上限及び平均的な値は次式で表される。

$$
\left.\begin{array}{lll}
\text { 上限值 } & r_{q} \leq 1.0 \text { で } & \frac{\mu_{m}}{\bar{\mu}}=\frac{2+2 r_{q}}{1+2 r_{q}} \\
& r_{q}>1.0 \text { で } & \frac{\mu_{m}}{\bar{\mu}}=\frac{4}{3}
\end{array}\right\}
$$

尚, ここでの平均的な值は厳密な意味での平均值ではなく，平均 值に近く，上限值との隔たりがおよそ1.3倍以下の值である。

(b) 累積塑性変形の片寄り

図 8 (b)には $T_{f}=2.5 \mathrm{sec}$ の場合の $\eta_{m} / \bar{\eta}$ を示す。 $r_{q}$ の増大につれ て $\eta_{m} / \bar{\eta}$ は急速に 1.0 に収束し, 上限値, 平均的な值な次式で表され る。

$$
\text { 上限値 } \quad: \quad \eta_{m} / \bar{\eta}=1.5-2.5 r_{q} \quad\left(r_{q} \leq 0.2\right)
$$$$
\text { 平均的な值： } \eta_{m} / \bar{\eta}=1.25-1.25 r_{q} \quad\left(r_{q} \leq 0.2\right)
$$

(c) 平均累積塑性変形倍率と平均塑性変形倍率の对応

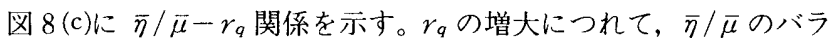
ツキ幅は減少し，下限値並びに設計用の準下限値が次のように表さ れる。

$$
\begin{aligned}
& \text { 下限值 } \left.\quad \begin{array}{ll}
r_{q} \leq 1.0 て ゙ & \frac{\bar{\eta}}{\bar{\mu}}=2+2 r_{q} \\
r_{q}>1.0 て ゙ & \frac{\bar{\eta}}{\bar{\mu}}=4.0
\end{array}\right\} \\
& \text { 準下限值： } \left.\begin{array}{ll}
r_{q} \leq 1.0 \text { で } & \frac{\bar{\eta}}{\bar{\mu}}=3+r_{q} \\
r_{q}>1.0 \text { で } & \frac{\bar{\eta}}{\bar{\mu}}=4.0
\end{array}\right\}
\end{aligned}
$$

尚，ここでの設計用とは，本論文で設計用として提案すると云う 意味である。

(d) 累積塑性変形倍率と最大塑性変形倍率との対応

図 8 (d)には $\eta / \mu_{m}-r_{q}$ 関係を示す。 $\bar{\eta} / \bar{\mu}, \mu_{m} / \bar{\mu}$ が既知であれば， $\eta / \mu_{m}$ は次式により求妨らる。

$$
\frac{\eta}{\mu_{m}}=\frac{2 \bar{\eta}}{\mu_{m}}=2\left(\frac{\bar{\eta}}{\bar{\mu}}\right)\left(\frac{\bar{\mu}}{\mu_{m}}\right)
$$

$\bar{\eta} / \bar{\mu}$ として下限值を用い, $\bar{\mu} / \mu_{m}$ として上限值を採れば, $\eta / \mu_{m}$ の 下限值が得られる。下限值は(25)，(29)式より次のように得られる。

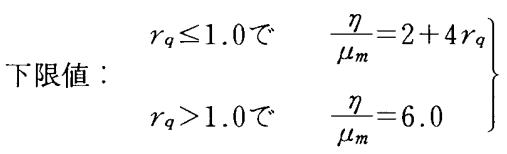

$\eta / \mu_{m}$ の設計值として下限值を採ることは $\eta / \mu_{m}$ のバラツキの大

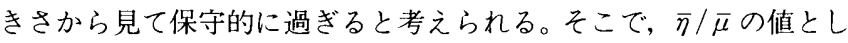
ては準下限值を採り， $\mu_{m} / \bar{\mu}$ としては平均的な值を採りこれを設計 值とすれば(26)，(30)式より次式が得られる。

$$
\left.\begin{array}{lll} 
& r_{q} \leq 1.0 \text { で } & \frac{\eta}{\mu_{m}}=4+4 r_{q} \\
\text { 設計值： } & & \frac{\eta}{\mu_{m}}=8.0
\end{array}\right\}
$$

尚，ここでの設計値とは，本論文で設計值として提案すると云う 意味である。

図 8 (d)の各図には実応答值と(25) （33)の諸式の值が比較してある。 (31)式に示される様に上述の諸式は互いに脈絡を持っている。(33)式は 設計值という意味で重要である。諸式は図 8 に示される様に $T_{f}$ に 対寸る依存性はない。

5ー2 バウシンガー効果を伴う完全弾塑性型の復元力特性を持つ

\section{場合}

図 9 にはバウシンガー効果 $\left(r_{B}=0.5\right)$ を伴う完全弾塑性型の復元 力特性を持つ系の応答を示す。この場合は全ての応答にわたって完 全弾塑性型 $\left(r_{B}=0\right)$ の場合の応答と大差ない。従って，(25)～(33)式 に示寸諸関係がそのまま適用できる。眓 9 の各図には(25)〜(33)式が実 応答值と比較されている。

\section{$5-3$ 剛性劣化型復元力特性を持つ場合}

図10には鉄筋コンクリート岡接骨組に対応する少化型復元力特性 （Clough 型）の場合の応答を示す。この場合も $\mu_{m} / \bar{\mu} に は(25) ，(26)$ 式

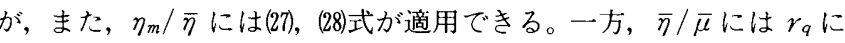
よる変化は殆ど見られず，下限值及び設計用準下限值は次のように

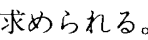

下限値 $: \frac{\bar{\eta}}{\bar{\mu}}=2$

準下限值： $\frac{\bar{\eta}}{\bar{\mu}}=2.5$

$\eta / \mu_{m}$ は次式で表される。

$$
\left.\begin{array}{ccc} 
& r_{q} \leq 1.0 \text { で } & \frac{\eta}{\mu_{m}}=2+r_{q} \\
\text { 下限值： } & & \\
& r_{q}>1.0 \text { で } & \frac{\eta}{\mu_{m}}=3.0
\end{array}\right\}
$$

(34)，(36)式及び(35)，(37)式より，この場合 $r_{q} \leq 1.0$ の範囲で $\mu_{m} / \bar{\mu}$ とし て次式を用いたことになる。 


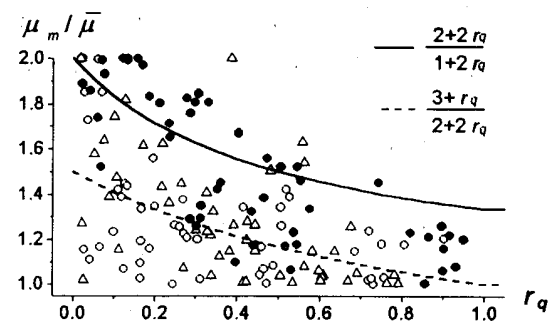

(a) $T_{1}=2.5 \mathrm{sec}$
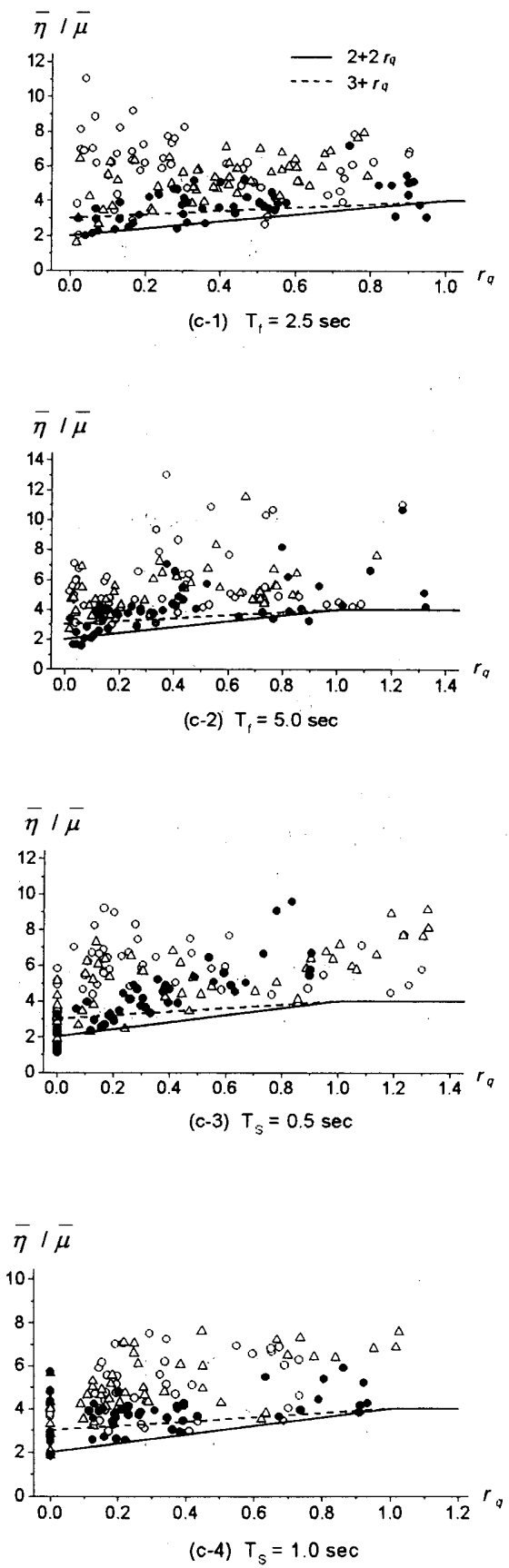

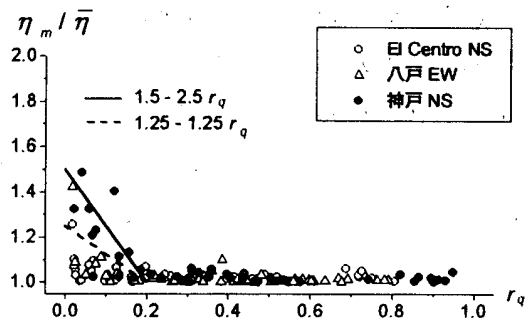

(b) $T_{1}=2.5 \mathrm{sec}$
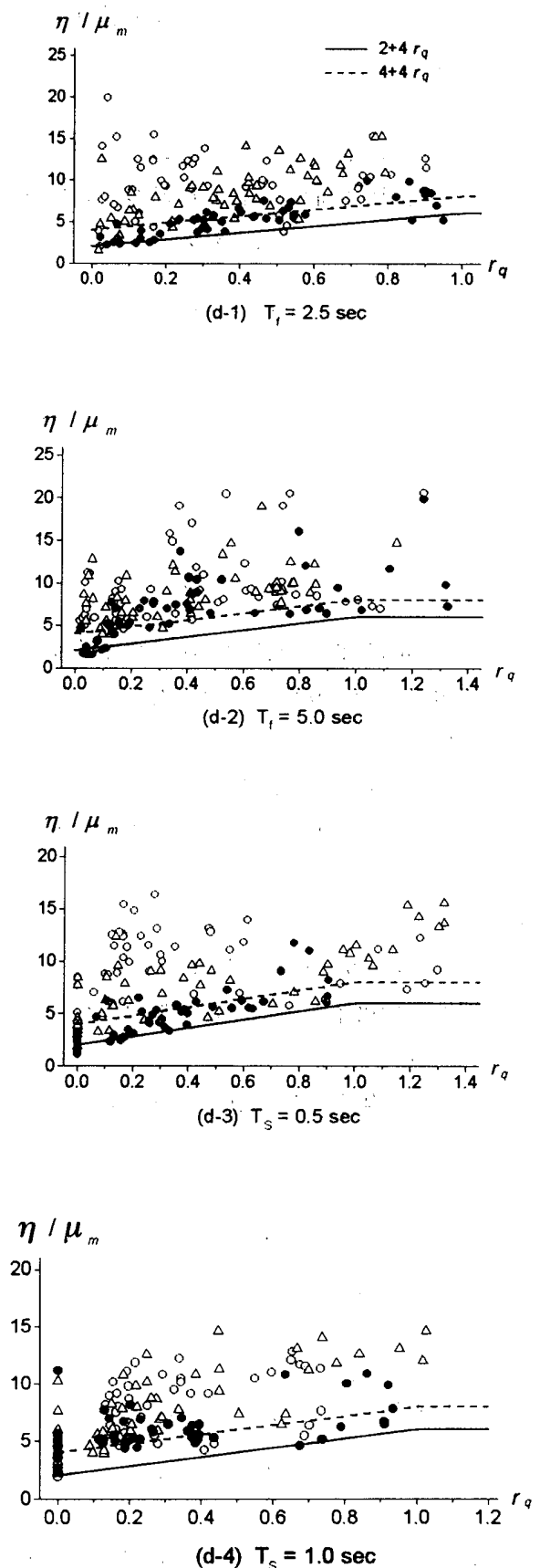

图 $8(\bar{\mu}+1) r_{k}$ に着目した芯答：完全弾塑性型 $\left(r_{B}=0\right)$ の場合 


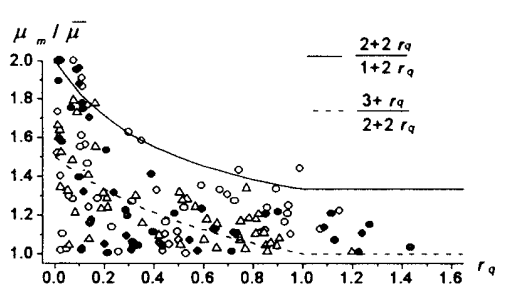

(a) $T_{1}=5.0 \mathrm{sec}$
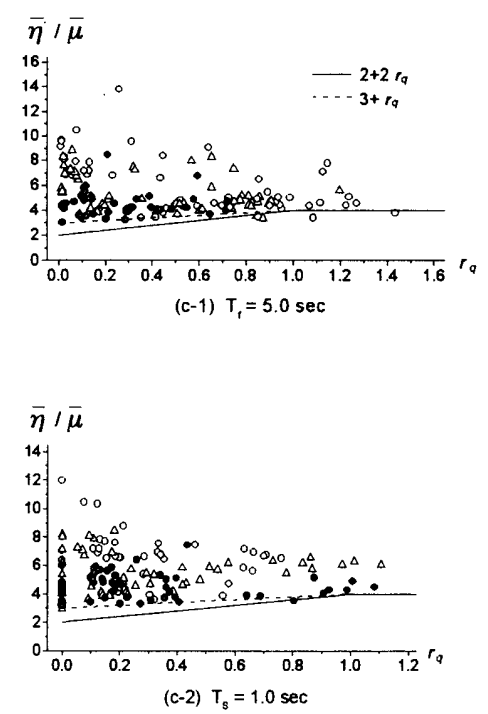

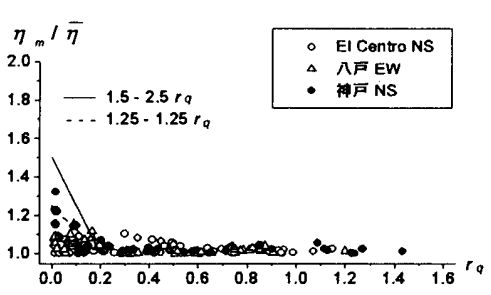

(b) $T_{f}=5.0 \mathrm{sec}$
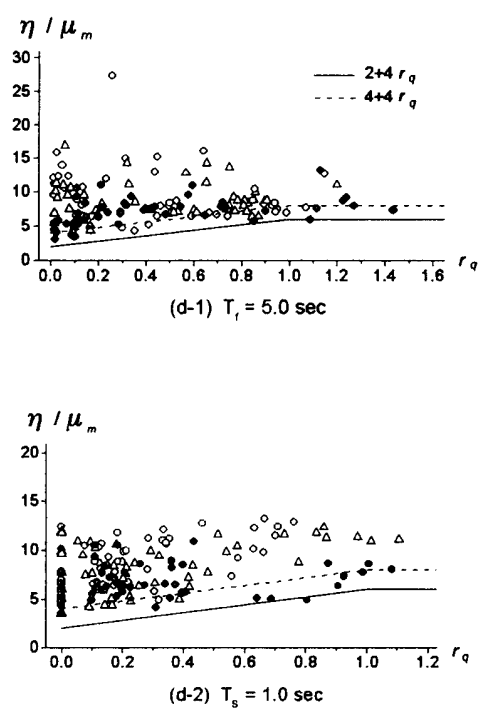

図 $9(\bar{\mu}+1) r_{k}$ に着目した応答：完全弾塑性型 $\left(r_{B}=0.5\right)$ の場合

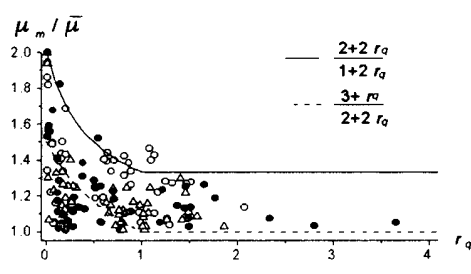

(a) $T_{1}=5.0 \mathrm{sec}$
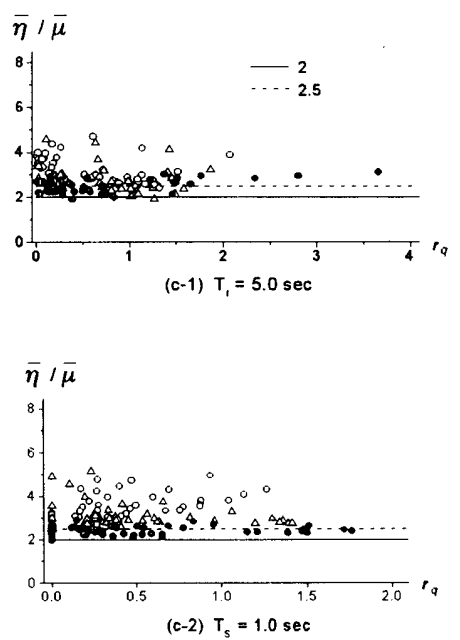

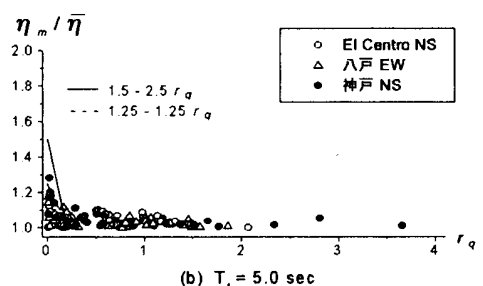

(b) $T_{1}=5.0 \mathrm{sec}$
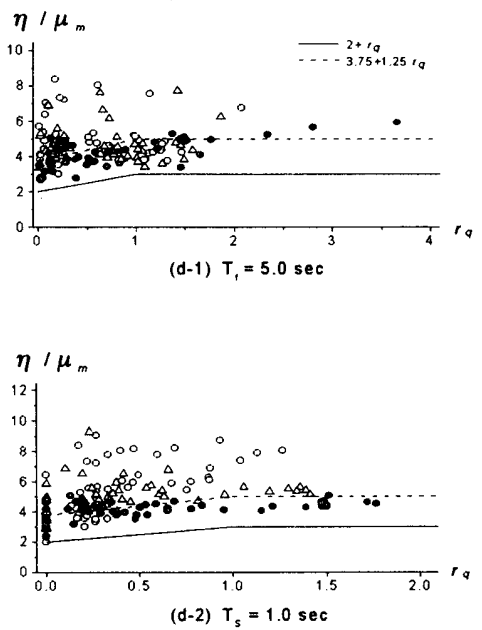

図10（ $\bar{\mu}+1 ） r_{k}$ に着目した答：Clough モデルの場合 


$$
\begin{aligned}
& \text { 上限値 }: \frac{\mu_{m}}{\bar{\mu}}=\frac{4}{2+r_{q}} \\
& \text { 平均的な值: } \frac{\mu_{m}}{\bar{\mu}}=\frac{5}{3.75+1.25 r_{q}}
\end{aligned}
$$

(25)，(38)式と(26)，(39)式は表現が異なるが殆ど同等である。

\section{6. 結語}

骨組の変形, エネルギーに関する応答諸量の対応関係を地震応答 解析により求め，エネルギー応答と変形応答を対応づける為に必要 な関係式を求めた。対象骨組はせん断型であり，一般化のため多層 とした。骨組は弾性挙動する柔要素と弾塑性挙動する岡要素から成 る柔剛混合構造である。剛要素の復元力特性は, 鋼構造風接骨組を 代表する完全弾塑性型とそれに Bauschinger 効果を付加したもの 及び鉄筋コンクリート剛接骨組を代表するClough モデルの 3 つの タイプのものを用いた。

用いた地震動はエネルギー入力の特性の異なる 3 種類である。地 震動の特徴としては，JMA 神戸 NS 記録の場合に最大変形が一方 向へ大きく片寄る傾向が強く, また, 最大変形に対する吸収エネル ギーが少ない傾向も現れ, 各評伍式の上限值ないし下限值をもたら 寸率が高いものとなり, 設計的観点から見て酷しい地震動であるこ とが判る。それは, 短時間に高いエネルギ一大力をもたらす地震動 であったことからも十分に領ける。しかし，他の地動記録と比べて 全く異質のものではなく，その応答は他の地震動のもたらす応答の バラツキの中に包含されるものである。

応答諸量は次のものである。

エネルギー応答に関わるもの：累積塑性変形倍率 $\eta$ 平均罢積塑性変形倍率 $\bar{\eta}$ 最大累積塑性変形倍率 $\eta_{m}$

最大変形応答に関的るもの：平均塑性変形倍率 $\bar{\mu}$ 最大塑性変形倍率 $\mu_{m}$

応答解析結果は次のようにまとめられる。

1) 変形忘答の相互関係を支配する最も重要なパラメー夕は柔剛要 素間の負担せん断力比 $r_{q}\left[=(1+\bar{\mu}) r_{k}\right]$ である。 $r_{q}$ の増大につれ
て応答諸量のバラツキは減少する。

2） $r_{q}>0.2$ では $\eta_{m} / \bar{\eta}$ は殆ど1.0に収束する。

3） $\mu_{m} / \bar{\mu}$ は極めてバラツキの大きい量であるが, $r_{q}>1.0 て ゙ 4 / 3$ 以 下の值に収束する。

4） $\bar{\eta} / \bar{\mu}$ も $r_{a}$ の增大につれて4.0程度の做に収束する傾向がある。

5) $\eta / \mu_{m}$ は $r_{q}$ の増大につれて $5 \sim 10$ 程度の値に収束する。

6 ）応答諸量はその上限値（ないし下限値）を表す簡単な関係式と して示された。

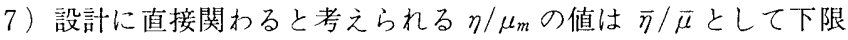
值に近い値を採り， $\mu_{m} / \bar{\mu}$ として平均的な值を採ることにより簡 単な式で表現することができ，設計值として提案した。

\section{参考文献}

1）秋山 丢：建築物の耐震極限設計 第 2 版, 東京大学出版会, 1987

2）高橋 誠, 秋山 宏：1995年兵庫県南部地震神户”海洋気象台記録に基づく エネルギー入力について, 日本建築学会大会学術講演梗概集 B, pp $213-214,1995$

3）長橋純男：入力エネルギーによる地震動強さの評価, 日本建築学会大会学: 術講演梗概集 B, pp.417-418, 1991

4）大石 昌, 曾目五月也：最近の 2 つの地震動に対する建築物の応答の工ネ ルギー入力に基づく比較、日本建築学会大会学術講演梗概集 B, pp. 509-510, 1995

5）中村友紀子, 壁谷澤寿海：構造物の地震時最大塑性芯答変形のエネルギー 入力速度による推定 (その 2 ), 日本建築学会大会学術講演梗概集 B, pp 587-588, 1996

6）中村孝也，堀 則男，杢上範夫，柴田明徳：鉄筋コンクリート構造物にお ける地震動入力エネルギーと忘答最大塑性率との関係, 日本建築学会大会 学術講演梗概集 B, pp.461-462, 1997

7）真柄环也，三宅辰也，五十峲博，田守伸一郎，笹川明：枠組壁工法建築 物の地震時最大応答変位に関する考察，日本建築学会構造系論文集 第 506号，pp.75-82，1998，4月

8）秋山厷：耐䈨性能の多梯化に対忘した耐震設計, 日本建築学会構造系論 文集 第472晨，pp.85-90，1995，6月

9）原田幸博，秋川宏：エネルギー集中型来剛混合骨組の耐震設計，日本建 築学会構造系論文集 第472号，pp.57-66，1995，6月

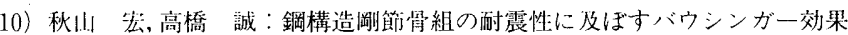
の影響, 日本建築学会構造系論文報告集 第418-号, pp.49-57, 1990, 12月

(1998年 3 月10日原稿受理，1998年.7月17日採用決定) 